\title{
Agency and Domestic Institutional Change: A Comparative History of Reform Experiences of Taiwan
}

\author{
Julius Lopez Porley
}

\begin{abstract}
This paper analyzes the reform experiences of Taiwan and the Philippines in comparative perspective to describe the causes and consequences of institutional change in these polities. The findings indicate that international and domestic events, critical or less, generate reform opportunities; but whether these events leads to institutional change and how hinges on the agency and capacity of actors.
\end{abstract}

Index Terms-Institutions, institutional change, human agency, Philippines, Taiwan.

\section{INTRODUCTION}

The standard models of institutional analysis maintain that mechanisms endogenous to institutions make them immutable. As such, they change in abrupt and dramatic manner only when exogenous shocks like wars or economic depression discredit or cause them to break down. Although these models provide compelling analyses of radical institutional modification, they cannot account for cases wherein exogenous shocks resulted not in sudden and complete departures from established practices but in gradual adaptation. Similarly, they cannot account for cases wherein non- or less critical moments eventuated in incremental institutional variation. The reform experiences of Taiwan and the Philippines are a good case in point. If indeed crises foment a complete break or systemic overhaul, why then in the case of the former, the tremendous environmental pressure for Lee Teng-hui to introduce fundamental reforms in the political system triggered a gradual process of constitutional reform whereas, in the case of the latter, the narrow electoral victory of Fidel Ramos, a less critical event, was followed by a marked reversal in the "rules of the game" of the Philippine telecommunications industry?

This paper analyzes in comparative perspective these reform experiences to describe the causes and consequences of institutional change in these countries. It contends that exogenous shocks are not the only, or even the most essential, factor in the process of institutional change. In order for institutional change to take place enterprising actors must actually exploit the opportunities these rare events create and actively promote systemic fine-tuning. It commences as follows. The next part offers a theoretical discussion. It is followed by the presentation of cases. The last part concludes.

Manuscript received March 6, 2013; revised May 6, 2013.

Julius Lopez Porley is with the Department of Political Science, University of Makati, Philippines (e-mail: juliuslporley@gmail.com).

\section{InSTITUTIONS AND INSTITUTIONAL CHANGE}

All forms of social relations subscribe to rules. These rules - or what is referred to in the social sciences as institutions induce humans to behave in such a way that makes social life possible. It is through them in fact that society acquires structure and consistency [1].

The recognition of the indispensable role of institutions in society has inspired deep academic interest and accordingly diverse descriptions about how they shape behavior, how they emerge, and why they change. One school of thought, Rational Choice Institutionalism, conceives institutions as stable devices of compliance and cooperation. According to this view, the ability of institutions to reduce transaction cost and uncertainty makes them self-enforcing and, thus, impervious to change [2]. Yet they change whenever exogenous shocks destabilize them and prompt actors to cobble up new ones [3].

Another model, Historical Institutionalism, conversely, depicts institutions neither as intentional nor efficient implements but rather as accidental legacies of past political conflicts. According to this view, institutions are driven by power; and their ability to create large constituencies structures the interest of institutional actors in ways that ensure institutional persistence [4]. Although change may proceed, but only in abrupt and massive fashion and in response to alterations in the balance of power underpinning institutions caused by critical junctures [5].

Notwithstanding their ontological differences, essentially, both of these models agree that mechanisms endogenous to institutions keep them stable, and for that reason, only exogenous shocks can cause them to transform. Despite their best efforts, though, both models cannot comprehensively account for how and why institutions change. By privileging the ability of actors to deliberately create and control institutions and their outcomes, Rational Choice Institutionalism ignores the power asymmetries inherent in institutional dynamics [6]. On the other hand, by putting causal emphasis on environmental pressures, Historical Institutionalism discounts the potential of human agents to initiate the process of institutional change [7]. Institutions do not change by themselves; they are changed by purposive actors to advance their own strategic interests [8]. Yet these actors cannot invariably bring about their intended goals when promoting reforms as their institutional context always puts constraints on their activities [9].

To put forth a comprehensive explanation as to how and why institutions change, it is imperative therefore for scholars of institutions not to train their analytical sight exclusively on parametric factors. They ought to recognize as 
well the vital role of human agents - who prefer whether or not to exploit these exceptional events to initiate reforms and how - in it. The theory of institutional change developed by Cortell and Peterson [10] is instructive regarding this matter.

According to this theory, institutional change is contingent upon three factors: 1) the environmental triggers; 2) the agents of change; and 3) the institutional capacity of change-agents. Change may be episodic, where institutional patterns are reinvented so as to break with prevailing customs and procedures, or incremental, where reform is limited to a specific issue area or task environment. Trigger events, critical or not, can open "windows of opportunity" if they discredit the logic of existing arrangements, expose the inadequacies of the rules of the game or generate overwhelming societal costs and accordingly afford change-agents autonomy to advance their transformative agenda. But whether change, of the episodic or incremental type, will ensue depends on the capability of actors to recognize and exploit the reform opportunities generated by these events. Several elements influence actors to act as agents of change: their appreciation of the urgency of reforms, the political incentives of their reformist project, their belief system or ideological background, and their power position.

Applying this theory as a guidepost to analyze and compare the reform accomplishments of Lee Teng-hui in Taiwan and Fidel Ramos in the Philippines can validate the potency of its explanation.

\section{CAses of Institutional Change}

\section{A. The Constitutional Reform of Lee Teng-Hui}

The democratic transition of Taiwan in the mid-1980s punctured the rules of the political game that justified the authoritarian control of the mainlander Koumintang (KMT) party-state over the island-nation for half a century. Yet contrary to the theoretical predictions of mainstream theories, a systemic overhaul did not unfold. What actually ensued was a slow-phased adjustment in one aspect of the political system - the constitutional rule on the election of the president. This reform episode provides a mine of information regarding the causal mechanics of institutional change, particularly, the role of human agency in it. It shows how the ideas, interests, and institutional capacity of change-agents mediate between environmental pressures and institutional change.

Lee Teng-hui assumed the presidency of Taiwan while the KMT was facing its worst political crisis since its transfer to the island in 1949. Internally, the widespread public mobilization for fundamental democratic reforms was undermining the social control of the émigré party-state. Externally, reacting to the island's instability, the bellicose Peoples' Republic of China (PRC) was threatening to launch its military might against it [11].

As president, Lee understood the gravity of the situation and recognized the imperative need to steer Taiwan out of the political storm. The problem, however, was his weak power position within the KMT structure was crippling his abilities to do so. On the account of his ethnic background, he was politically isolated and lacked the support of the key organs of the party-state. Compounding his predicament, the conservative party elders refused to accept the legitimacy of his authority; they simply regarded him as a nominal head mainly to appease the restive Taiwanese public. Even some of them were maneuvering to have him replaced by a more reliable mainlander who could guarantee the commitment of the KMT to its original mission of reunification with and asserting its legal rights over mainland China [12].

Taiwan's political crisis was forcing Lee to make a difficult choice between the path of KMT conservatism and radical Taiwanese nationalism. But in his perception neither of them was offering him good prospects. On the contrary, choosing between the two would greatly undermine the survival of his presidency and the island-nation itself. On the one hand, towing the old line of reunification would further isolate Taiwan diplomatically. However, giving up the hallowed mission could lead to a destructive societal discord. On the other, ignoring the Taiwanese nationalist sentiment would further alienate domestically the already unpopular KMT government. However, asserting Taiwan's independence would set off PRC's military aggression.

To get out of this predicament, Lee knew he must find a way to fortify his position vis-à-vis his mainlander party elders and enhance legitimacy of his rule in the eyes of the Taiwanese public without risking domestic upheaval. He found one in democratic consolidation [13]. In his calculation, by completing the process of democratization initiated by his predecessor and establishing a constitutional government within the framework of the 1947 Constitution - the legal basis for KMT's rule over mainland China prior to its transfer to Taiwan - he could guarantee the continuity of the KMT-era constitutional order and thus assure the party elders of his commitment to its raison d' être. Also, with it, he could entice the democratic opposition to support his reform effort [14].

Promoting constitutional democracy, though, as an institutional solution to the political crisis posed another dilemma for him: He had to terminate the "Temporary Provisions" and revert to the original governmental design laid down by the 1947 Constitution. ${ }^{1}$ This would mean reducing the powers of the president to insignificance and conferring greater governmental powers to the Legislative Yuan (LY) and the Executive Yuan (EY), where his mainlander adversaries are most influential. At that particular juncture of his presidency, doing so would be inimical to the

\footnotetext{
${ }^{1}$ The constitution promulgated by the KMT when it assumed authority over mainland China after WWII, the 1947 Constitution, set in place a semi-presidential or dual executive system for Republic of China (nationalist China). In this setup executive power is divided between the prime minister, who heads the cabinet, and the president. The president nominates the prime minister, but the constitution lodges more power to the latter. The prime minister presides over cabinet meetings and the president cannot issue orders without the prime minister's signature. The prime minister is accountable to the Legislative Yuan since his nomination needs the approval of the body. However, because of the KMT's war against the communists and its subsequent defeat and transfer to Taiwan in 1949, the 1947 Constitution was temporarily suspended. The mainlander KMT regime governed Taiwan through what became known as the "Temporary Provisions Effective During the Period of National Mobilization for Suppression of Communist Rebellion" or "Temporary Provisions". This served as the legal sanction of the KMT authoritarian state and the centralization of political power in the hands of the president of Republic of China who is also the chairman of the only legal political party, the KMT.
} 
stability and efficacy of his rule. To avert this complication, thus, he enacted additional articles to the existing constitution to institutionalize a strong, popularly-elected presidency. He preferred to pursue such reform in this manner instead of amending the 1947 Constitution or drafting a new one because, again, he was wary of the implications of either one of them to the parlous political condition of Taiwan. Constitutional revision would certainly spark adverse reactions from the conservative mainlanders. Besides, he did not have the means to do so as anti-reform forces still dominate the state institutions specifically the National Assembly - the branch mandated by law to entertain amendments and revisions to the Constitution. Moreover, drafting a new constitution may be interpreted by the PRC as a declaration of Taiwan's independence and thus justify a declaration of war against the island [15].

Lee's decision to revise the country's rules for electing its head of government was not shaped solely by his political interest and his perception of what was being demanded of him by his problematic context. Partly, his nationalist sentiment played a considerable role in it. Even though he did not explicitly show it, he resented the prevailing condition in which political power was exercised by non-Taiwanese. Being a native himself, he wanted the Taiwanese to take charge of their own destiny as a nation by investing them the power to choose their own president [16].

Although he developed a clear reform agenda, Lee did not carry it out right away because his weak political base within the KMT party-state structure inhibited his actions. His reformist faction within the KMT was still a minority while the mainlander old guards controlled the different branches of the government most especially the National Assembly. That is to say, though the political crisis discredited the established order of things, it did not give him sufficient autonomy to seize the moment and initiate systemic fine-tuning. The window of opportunity opened up only years later after a series of ad hoc and incremental steps he had taken to build his capacity - e.g., recruiting more Taiwanese into the KMT and forging an effective reform coalition with the opposition Democratic People's Party (DPP) - made the institutional context less constraining, thereby providing him greater freedom of action for constitutional tinkering.

But even if he had acquired political autonomy then, still, Lee could not have successfully achieved his desired reform if the Taiwanese political system itself did not enable him to do so. In other words, his institutional context did not only constrain but also actually enabled him. One enabling condition which abetted his reform pursuit was the 1991 decision of the Council of Grand Justices (the institution responsible for interpreting the Constitution) mandating the retirement of all the members of Taiwan's representative institutions originally elected prior to the transfer of KMT to the island in 1949. The historic decision paved the way for his loyal supporters to capture the overwhelming majority of the seats in these institutions including the National Assembly when elections were held the following year, in 1992 [17].

Another enabling condition was provided by the KMT's organizational structure. With his success in "Taiwanizing" the KMT, he acquired greater power and influence in setting the items, parameters, and rules of constitutional reforms. Moreover, by exploiting his formal authority as party chief and head of state, he was able to deploy the administrative and financial assets of the government and utilize them to build his own political clients and constituency within and outside the party [18]. This was particularly true in the case of the business sector which was lured to support him by his pledge to implement economic liberalization [19].

Nonetheless, Lee's successful attempts at building his reform capacity generated consequences that ironically eroded the KMT's political control. As a result of his alliance with business, local political elites, and criminal groups, particularistic elements gained an unprecedented access to the presidency and voice in the policy structure [20]. Graft, corruption and bribery became pervasive during his term. Largely because of this, the KMT gradually lost its electoral base and, in 2000, cost it the presidency [21].

\section{B. Telecommunications Reform of Fidel Ramos}

The telecommunications reform of Fidel Ramos is another interesting case that can provide invaluable insights as to how human agency conditions the manner, trajectory and outcome of change. This reform episode suggests that even non- or less critical events like change of administration can potentially create enabling conditions for reform-oriented state actors to engender a fundamental break in the usual pattern of interaction between the state and society.

When Fidel Ramos ascended to the presidency in 1992, he launched a serious attempt to reform the country's political economy. One of the crucial components of his ambitious reform project was the dismantling of monopolies in strategic industries of the country. As a demonstration of his resolve, he singled out for liberalization the moribund and inefficient telecommunications sector which, for decades, was dominated by the Philippine Long Distance Telephone Company (PLDT), a telecom giant under the control of one of the most influential political families in the country and one of the key supporters of his presidential bid - the Cojuangcos.

However, before reform could proceed, Ramos had to overcome first a number of hurdles. For obvious reasons, his reform entailed huge amount of political capital to implement. Unfortunately, he had very little of it to bank on. He was not only a minority president (he only garnered $23 \%$ of the total votes during the presidential election), he lacked also congressional support. Out of the more than 200 members of the House of Representatives only 36 and out of the 24 members of the Senate only two belonged to his party [23]. But the more challenging obstacle was the structural power of the Cojuangco interest: The family had at its beck and call some of the most powerful elements of the Philippine government [24]. Interestingly, even though all the cards were stacked against his favor, Ramos succeeded in his bold and ambitious campaign to force the mighty PLDT to submit itself to market competition and open the telecommunications industry to different independent players. Thanks to his reform, access to telephone lines improved radically, and mobile phone usage increased exponentially [25]. 
Like in the case of Lee, Ramos succeeded in orchestrating reform because a more enabling institutional context afforded him some degree of autonomy from short-term political constraints and modest capacity to enact his reform vision. Through his executive leadership and political adroitness, he created opportunities that allowed him to "loosen the ground for reform" at all fronts. He remedied his institutional inadequacy vis-à-vis Congress by brilliantly using the power and resources of his office and harnessing the unwritten rule governing the conduct of relations between the president and the legislature, i.e., the disbursement of pork barrel funds, to recruit the majority of the members of Congress into his political party and secure for him a reliable, multi-partisan legislative coalition [26]. Moreover, he exploited the democratic space enshrined by the 1987 Philippine Constitution to isolate the conservative forces protecting PLDT and to put added pressure on Congress to side with reform. For instance, through the activities of the consumer group Movement for Reliable and Efficient Phone System (MOREPHONES), which his own supporters helped organize, he was able to stir public opinion against the inefficient service of PLDT and, simultaneously, mobilize grassroots support for the institutionalization of competition in the Philippine telecommunications sector through the legislation of the 1995 Telecommunications Liberalization Act [27].

As good as he was as a military strategist Ramos managed also to deny his adversary the structural advantages it initially enjoyed in the judicial branch. Sometime in 1993, a group of investigative journalists published a report exposing how PLDT's own lawyer connived with no less than a magistrate of the Supreme Court to pen the high tribunal's decision regarding a case filed against PLDT by one of its competitors He took advantage of this corruption scandal to neutralize PLDT's resistance and force it to become amenable to liberalization. In addition, he capitalized on his legal mandate as chief executive to break up PLDT's monopoly. He issued a series of Executive Orders encouraging new players to enter the market and compete against PLDT [28]. He used as well his legal authority to appoint government representatives to the telecom's 11-member Board of Directors and maneuvered to secure a majority vote in it. He then brokered a deal with the company president to drop all opposition to the government's efforts to liberalize the telecommunications industry in exchange for his retention as president and CEO of the company [29].

The above discussion presents how Ramos turned the spokes of reform, but not why he did so. To clarify this matter, one has to look into his perception of the national situation, power interest and political ideas.

Even before he became president, Ramos already had a well-defined understanding of the institutional basis of the economic maladies of the Philippines. In his interpretation, the vicious cycle of the country's underdevelopment is rooted on "protectionism, the overweening influence on public policy of parochial interest groups and an inward-looking kind of nationalism" [30]. In order to put an end to it, it is imperative for the Philippine State to "insist that our business and political elites commit themselves unequivocally to the common good" [31]. When he came to power, he diligently pursued this development strategy and, drawing inspiration from the miraculous growth feats of East Asian NICs, tried to build the capacity of the Philippine State to guarantee the operation of a competitive market. In his calculation, by subjecting the economy to market pressures his government could loosen the grip of particularistic interests over Philippine political and economic life and accordingly drive the country's catch-up process [32].

The prevalence of free trade arrangements in the 1990s also played a significant role in the reform preference of Ramos. Ramos took office against the back draft of dramatic international and domestic shifts. Internationally, the Cold War has just ended and the new security climate was pushing nations to frame their security interests along economic lines. Participation in international organizations committed to a more liberal economic regime was rapidly becoming the international norm. Domestically, the withdrawal of the US military bases left the Philippines with dwindling American military and financial support at a time the economy was recovering slowly from a string of crises that had plagued the previous administration. Without American security and pecuniary guarantees, his government was forced to establish close ties with and rely upon its regional neighbors and participate actively in international economic arrangements such as the GATT, APEC, and the ASEAN Free Trade Agreement to generate capital wealth required to bankroll the country's industrialization [33]. However, he recognized that these engagements will not and cannot guarantee the Philippines a sustainable economic sinew unless he makes it ideal for entrepreneurship and productive activities by addressing the shortfalls of its political institutions [34].

It certainly helped as well that Ramos had a great sense of urgency to make sure that his government gets its act right and capitalize on the myriad opportunities that the international economic order was offering then. For him, it was the country's "last chance" to escape from economic obscurity and catch up with its rapidly developing neighbors [35]. Nonetheless, he pursued reform rather with extreme caution, mindful of the strong public opinion against heavy handed government intervention and due also to his constitutional sensitivities and own awareness of the Philippine State's institutional limitations. Moreover, the reform failures of the Marcos dictatorship hanged over his head, having witnessed firsthand how authoritarian state power was subverted and employed in predatory activities. This lesson informed his strategic decision to be less interventionist in rooting out oligarchic privileges, along with the protectionist economics that entrenched them, and instead harness the invisible hand of the market and the power of civil society to promote his reform objectives [36].

Be that as it may, his triumphs against the Cojuangco-led PLDT did not mean he was able to shape the flow and outcome of reform according to his will. Throughout the course of his reform campaign, other political institutions mounted effective resistance to frustrate the new order he wanted to institutionalize. The contentious struggle between pro- and anti-reform forces sent the trajectory of the reform initiative along a path which Ramos had neither really intended nor foreseen. Primarily, the opposition in Congress, arguing that the president had appropriated a legislative function when it issued directives to liberalize the 
telecommunication industry, took advantage of its control of the legislative process to insert provisions in the 1995 Telecommunications Act which in effect watered down what Ramos had accomplished to end monopoly and usher the entry of new players in the industry [37].

\section{CONCLUSION}

The purpose of this comparison is to emphasize that, contrary to what the mainstream explanatory frameworks maintain, exogenous shocks do not necessarily eventuate in abrupt and fundamental changes in existing institutional arrangements. Deploying the theory of Cortell and Peterson as guidepost in analyzing two different cases, this paper underscores the crucial function of human agency in the process of institutional change. In the case of Lee Teng-hui's constitutional tinkering and Fidel Ramos' telecommunications reform, state-initiated purposive projects followed a gradual, step-by-step institutional adaptation because: 1) the respective ideas, perception, and power positions of these political entrepreneurs mediated between their institutional context and reform outcomes; and 2) both sagaciously exploited the reform opportunities generated by autonomy-producing and institutionally-enabling trigger events (such as democratic pressures in the case of the former, and government change, in the case of the latter).

The comparison suggests that state actors are most likely to summon institutional change if domestic and/or international events, critical or less, generate constraint-reducing as well as autonomy-producing societal costs. However, whether, institutional modification will take place and how depends on the strategic decision of consequential actors acting as change-agents to capitalize on the reform opportunities attending these environmental punctures. In order for institutional change to actually proceed, state actors must be eager and capable to transform existing institutions.

But this is not to say that political actors can mold their institutional context according to their own purposes or intentions. Human agents, how willful and capable they may be, operate in a specific institutional setting which can impose considerable limits on their enterprises. This is why attempts at modifying existing institutional arrangements invariably incarnate unintended consequences that carry significant impacts on the process and outcome of change itself. Reform outcomes are path dependent. As such, though the power interest, environmental perception, and political calculation of human agents condition when and how they can work in favor of institutional change, still, their institutional setting somehow exerts influence as to what kind or form of reform is most likely to occur.

\section{REFERENCES}

[1] G. Hodgson, "What are institutions?" Journal of Economic Issues, vol. 40, no. 1, pp. 1-25, March, 2006, pp. 2.

[2] B. Weingast, "Rational choice institutionalism," in Political Science: The State of the Discipline, I. Katznelson and H. Milner, Eds. New York, pp. 660-692, 674-690, 2002.

[3] M. Levi, "A model, a method, and a map: rational choice in comparative and historical analysis," in Comparative Politics:
Rationality, Culture, and Structure, M. I. Lichbach and A. Zuckerman, Eds., New York, Cambridge University Press, pp. 19-41, 1997.

[4] K. Thelen and S. Steinmo, "Historical institutionalism in comparative politics," in Structuring Politics: Historical Institutionalism in Comparative Analysis, K. Steinmo, K. Thelen, and F. Longstreth, Eds. Cambridge: Cambridge University Press, 1992, pp. 9.

[5] S. Krasner, "Approaches to the state: alternative conceptions and historical dynamics," Comparative Politics, vol. 16, pp. 223-244, 1984.

[6] V. Schmidt. "Give peace a chance: reconciling four (not three) new institutionalisms," in Ideas and Politics in Social Science Research, D. Beland and R. Cox, Eds., Oxford University Press, 2010, pp. 84.

[7] V. Schmidt, "Give peace a chance: reconciling four (not three) new institutionalisms," in Ideas and Politics in Social Science Research, D. Beland and R. Cox, Eds., Oxford University Press, 2010, pp. 85.

[8] K. Thelen and S. Steinmo, "Historical institutionalism in comparative politics," in Structuring Politics: Historical Institutionalism in Comparative Analysis, K. Steinmo, K. Thelen, and F. Longstreth, Eds., Cambridge: Cambridge University Press, 1992, pp. 17.

[9] A. Cortell and S. Peterson, International Relations, Domestic Politics, and Institutional Change, Lexington Books, 2003, pp. 6.

[10] A. Cortell and S. Peterson, International Relations, Domestic Politics, and Institutional Change, Lexington Books, 2003, pp. 8-26.

[11] R. Kagan, Taiwan's Statesman: Lee Teng-Hui and Democracy in Asia, Naval Institute Press, 2007.

[12] L. Chao and R. Myers, "The First Chinese Democracy: Political Development of the Republic of China on Taiwan, 1986-1994," Asian Survey, vol. 34, pp. 213-230, Mar. 1994.

[13] T. H. Lee, Creating the Future: Towards a New Era for the Chinese People, Taipei: Government Information Office, 1992, pp. 65.

[14] H. Tien and T. Cheng, "Crafting democratic institutions in Taiwan," The China Journal, no. 37, pp. 1-27, Jan. 1997.

[15] M. Tien and Y. Chu, "Building democracy in Taiwan," The China Quarterly, vol. 148, pp. 1141-1170, Dec. 1996.

[16] T. H. Lee, the Road to Democracy: Taiwan's Pursuit of Identity, PHP Institute, Inc., 1999, pp. 19.

[17] S. Leng and C. Lin, "Political change on Taiwan: transition to democracy?" The China Quarterly, vol. 136, pp. 805-839, 1993.

[18] S. Hood, "Political change in Taiwan: the rise of kuomintang factions," Asian Survey, vol. 36, pp. 468-482, May 1996.

[19] P. C. Pe and J. H. Chang, "The Limits of Statecraft: Taiwan's Political Economy under Lee Teng-hui," in Sayonara to the Lee Teng-hui era: politics in Taiwan, 1988-2000, W. C. Lee and T. Y. Wang, Eds., University Press of America, 2003, pp. 113-148.

[20] J. Quah, Curbing corruption in asian countries: an impossible dream? Emerald Group Publishing, 2011, pp. 181.

[21] J. Jacobs, Democratizing Taiwan, Brill, 2012, pp. 181

[22] O. Caoili, "The restored philippine congress," in Philippine Politics and Governance An Introduction, N. Morada and T. Encarnacion Tadem, Eds., Quezon City: Department of Political Science, University of the Philippines, 2006, pp. 316.

[23] S. Coronel, "Monopoly," in Porks and Other Perks, S. Coronel, Ed., Quezon City: Philippine Center for Investigative Journalism, 1998, pp. 113-149

[24] P. Abinales and D. Amoroso, State and society in the Philippines, Pasig City: Anvil, 2005, pp. 248.

[25] P. Hutchcroft, "After the fall: the prospects for political and institutional reform in post-crisis Thailand and the Philippines," Government and Opposition, vol. 33, no. 4, pp. 473-497, 1999.

[26] L. Salazar, Getting a Dial Tone: Telecommunications Liberalization in Malaysia and the Philippines, Institute of Southeast Asian Studies, 2007, pp. 230.

[27] L. Salazar, Getting a Dial Tone: Telecommunications Liberalization in Malaysia and the Philippines, Institute of Southeast Asian Studies, 2007, pp. 234-235.

[28] L. Salazar, Getting a Dial Tone: Telecommunications Liberalization in Malaysia and the Philippines, Institute of Southeast Asian Studies, 2007, pp. 241.

[29] T. Scott, Democracy and Discipline: Fidel Ramos and His Presidency, UST Publishing House, 2006, pp. 26.

[30] F. V. Ramos, State of the Nation Address, July 26, 1993, quoted in J. Rocamora, Breaking Through, Manila: Anvil, 1994, pp. 174.

[31] J. Rocamora, Breaking Through, Manila: Anvil, 1994, pp. 183.

[32] R. Bernardo and M. C. Tang, "The political economy of reforms during the ramos administration," Commission on Growth and Development Working Paper, no. 9, World Bank, 2008, pp. 12-13.

[33] T. Scott, Democracy and Discipline: Fidel Ramos and His Presidency, UST Publishing House, 2006, pp. 44. 
[34] J. Abueva, President Fidel V. Ramos and His Administration, University of the Philippines, 1998, pp. 175.

[35] P. Hutchcroft, Booty Capitalism: The Politics of banking in the Philippines, Ateneo de Manila University Press, 2001, pp. 246.

[36] L. Salazar, Getting a Dial Tone: Telecommunications Liberalization in Malaysia and the Philippines, Institute of Southeast Asian Studies, 2007, pp. 249.

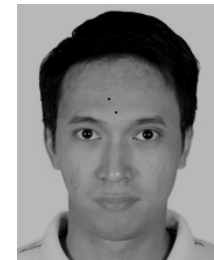

Julius Lopez Porley is a faculty at the University of Makati, Philippines. He obtained his B.A. and M.A. Political Science (Honors) degrees at the Royal and Pontifical University of Santo Tomas, Manila, Philippines. Currently, he is completing his $\mathrm{PhD}$ in Development Studies. His research and teaching interests include public policy, state-society relations, and comparative political economy. 